\title{
高強度材料を用いた小鉄骨 SRC 柱の繰り返し荷重下における耐力 \\ STRENGTH OF SMALL SIZE STEEL ENCASED REINFORCED CONCRETE COLUMNS WITH HIGH STRENGTH MATERIALS UNDER CYCLIC LOADING
}

\author{
滝口克已*，長嶋俊雄**，伊礼朋 次*** \\ Katsuki TAKIGUCHI, Toshio NAGASHIMA and Tomotsugu IREI
}

\begin{abstract}
This paper discusses the strength of a new SRC column. The SRC column is a small size steel encased reinforced concrete column using high strength concrete and high strength hoops. This SRC column is developed in order to have high shear carring capacity and ductitle performance.

Seven SRC column specimens were provided and tested. The concrete section of the specimens was $20 \times 20 \mathrm{~cm}$, the steel section $100 \times 50 \times 5 \times 7 \mathrm{~mm}$. Each specimen was subjected to cyclic and reversal bending moment and shear force under constant axial force. Experimental results indicate that the new SRC column has adequate properties as expected.
\end{abstract}

Keywords : SRC column, small size steel, high-strength concrete, high-strength hoop, shear strength flexual strength

鉄骨鉄筋コンクリート柱, 小鉄骨, 高強度コンクリート, 高強度フープ筋, 世ん断強 度, 曲げ強度

\section{1. 序}

本研究は, 通常の鉄骨鉄筋コンクリート (SRC) 柱 と比較して，次に示す三つの特色を有する SRC 柱の開 発に関する。

（1）コンクリート強度が比較的高い。

(圧縮強度 $400 \sim 600 \mathrm{~kg} / \mathrm{cm}^{2}$ 程度)

（2）コンクリート断面に対する鉄骨断面が比較的小さ い。

(鉄骨断面せいがコンクリート断面せいの半分程度)

（3）必要に応じて高強度のフープ筋を用いる。

(降伏点強度 $7000 \sim 10000 \mathrm{~kg} / \mathrm{cm}^{2}$ 程度)

前報”では，柱せい $(D)$ に対して，柱のクリア高さ $(h)$ が 2 倍, すなわち, $h=2 \cdot D$ の試験体で, フープ筋の強 度と量を実験パラメーターとした柱頭・柱脚・逆対称偏 心圧縮単調載荷実験の結果を報告し, 本研究で対象とし ている SRC 柱が材料特性を有効に活用しうる複合構造 システムのひとつになり得る可能性を示した。

高強度のコンクリートおよびフープ筋を用いた小鉄骨 $\mathrm{SRC}$ 柱のせん断耐力に関する前報の結論は以下のとお りである。

（1）降伏点強度 $9000 \mathrm{~kg} / \mathrm{cm}^{2}$ 級の高強度フープ筋の
強度を低減することなくせん断耐力を算定できる。

（2）圧縮強度 $500 \mathrm{~kg} / \mathrm{cm}^{2}$ 級の高強度コンクリートを 用いる場合も普通強度のコンクリートと同様に曲げ およびせん断耐力を算定できる。

（3）小鉄骨によってコンクリートが分断されるという ことは無視し，コンクリートの全断面が有効に働く

と考えてせん断耐力を算定できる。

前報”で報告した実験に引き続き，同様の柱試験体を 製作し，一定軸力下で正負交番の繰り返し曲げ・せん断 実験を行い，繰り返し荷重下における耐力および変形性 状を調べることにした。，奏験パラメーターは，前報”同 様, フープ筋の強度と量 (間隔)である。

本論文は，この奏験について論じる。

\section{2. 試験体}

試験体のコンクリート断面は $20 \times 20 \mathrm{~cm}$, 試験体柱の クリア高さは $40 \mathrm{~cm}$ とした。この試験体寸法であれば, せん断補強筋の少ない試験体は，せん断によって耐力が 支配されるであろうと予想されることが，この寸法にし た理由である。

$20 \times 20 \mathrm{~cm}$ のコンクリート断面に対して鉄骨は, 100

\footnotetext{
$*$ 東京工業大学工学部建築学科 教授 $\cdot$ 工博

竹中工務店技術研究所

*** 戸田建設 (元東京工業大学大学院生)
}

Prof., Dept. of Architecture and Building Eng., Faculty of Eng., Tokyo Institute of Technology, Dr. Eng.

Research and Development Institute, Takenaka Corporation Toda Corporation 
$\times 50 \times 5 \times 7 \mathrm{~mm}$ の $\mathrm{H}$ 形鋼しした。鉄骨断面のせいのコ ンクリート断面のせいに対する比は，強軸で 0.5 , 抲軸 で 0.25 である。通常の SRC に比較して, 鉄骨断面の コンクリート断面に対する比率は小さくなっている。

主筋は 4-D 13 （主筋比 $P_{g}=0.635 \%$ ）とした。フー プ筋には, 強度の異なる 3 種, すなわち, 降伏点強度が $9000 \mathrm{~kg} / \mathrm{cm}^{2}$ 級 (以下フープ A と記す), $4000 \mathrm{~kg} / \mathrm{cm}^{2}$ 級（同フープ B)，17000 kg/cm² 級（同フープC）のも のを使用した。フープ A およびフープ B は溶接閉鎖型 とし,フープC は溶接閉鎖型フープを作製することが 難しく，スパイラル型とした。フープ筋 $(4 \mathrm{~mm} \phi)$ の 強度と間隔が実験パラメーターである。間隔は, $2 \mathrm{~cm}\left(P_{w}\right.$ $=0.63 \%), 5 \mathrm{~cm}\left(P_{w}=0.25 \%\right), 10 \mathrm{~cm}\left(P_{w}=0.125 \%\right)$ のいずれかである。フープCの降伏点強度は，開発目 標としているフープ筋強度（降伏点強度 $7000 \sim 10000$ $\mathrm{kg} / \mathrm{cm}^{2}$ 程度）をはるかに超えている。このフープ筋を 用いた理由は，せん断補強量（フープ筋比 $P_{w}$ とフープ 筋の降伏点強度 $\sigma_{w y}$ の積, $P_{w} \cdot \sigma_{w y}$ と考える）を相当大 きくし，確実に曲げ破壊する試験体を作製するためであ る。

試験体は 7 体であり,その一覧を Table 1 に示す。フ一 プ筋 3 種の力学特性を Table 2 に，鉄骨の力学特性を Table 3 に, 主筋の力学特性を Table 4 に示す。試験体 をFig. 1 に示す。柱試験部の両側に加力のためのスタッ ブ (梁型) を設けている。スタッブ部分で鉄骨とコンク リート間でせん断力が確実に伝達されるように，シアー キーを配している。溶接閉鎖型フープは溶接箇所が柱に 加わるせん断力と直交方向に位置するように配した。
コンクリートは，柱を水平に置き，鉄骨断面の強軸方 向から打ち込んだ。コンクリートの調合を Table 5 に示 す。コンクリート打設後, 表面を仕上げて, 水分を含ま せた新聞紙で打設面の湿潤状態を保ち，打設面がある程 度硬化したら湿らせた砂を入れた布袋を載せ，湿潤状態 を保ちながら 1 週間養生した。その後, 型枠を脱型し, 室内に放置した。コンクリートの力学特性を Table 6 に 示す。
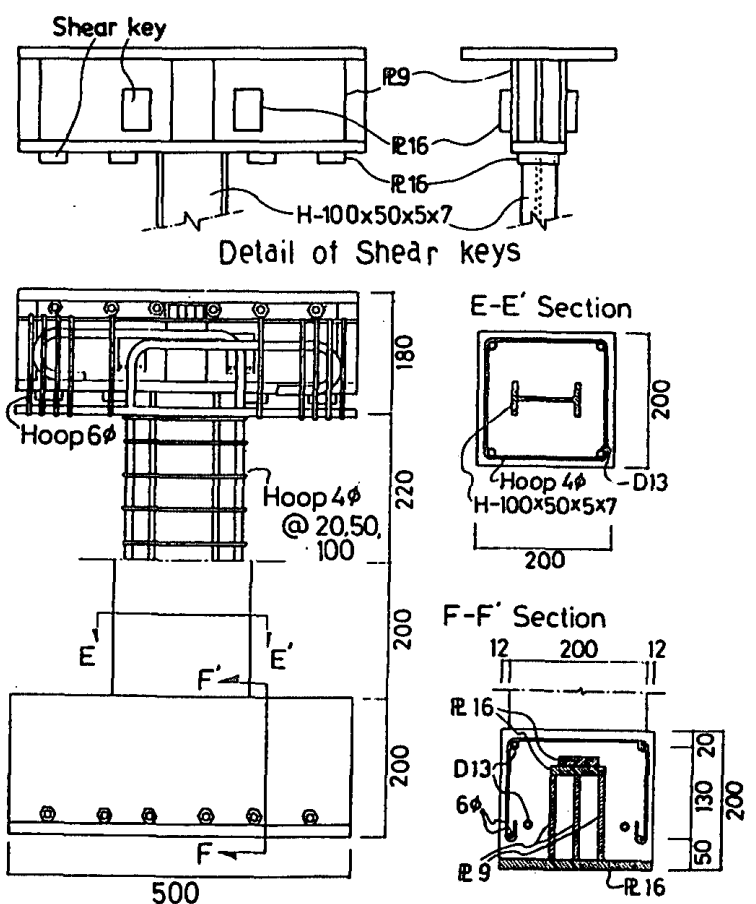

Fig. 1 Specimen
Table 1 List of specimens

\begin{tabular}{|c|c|c|c|c|}
\hline $\begin{array}{l}\text { Name of } \\
\text { specimen }\end{array}$ & $\begin{array}{c}\text { Shear } \\
4 \phi\end{array}$ & $\begin{array}{l}\text { reinf. } \\
P w(8) \\
\end{array}$ & Hoop & $\begin{array}{l}\text { Pw. } \sigma w y \\
\left(\mathrm{~kg} / \mathrm{cm}^{2}\right)\end{array}$ \\
\hline SRC-20-A-R & \multirow{3}{*}{$@ 20$} & \multirow{3}{*}{0.63} & A & 59.9 \\
\hline SRC-20-B-R & & & B & 30.0 \\
\hline SRC-20-C-R & & & c & 109.1 \\
\hline SRC-50-A-R & \multirow{2}{*}{ @50 } & \multirow{2}{*}{0.25} & A & 23.8 \\
\hline SRC-50-B-R & & & B & 11.9 \\
\hline SRC-100-A-R & \multirow{2}{*}{$@ 100$} & \multirow{2}{*}{0.125} & A & 11.9 \\
\hline SRC-100-B-R & & & B & 6.0 \\
\hline
\end{tabular}

Table 2 Mechanical properties of hoop reinforcement

\begin{tabular}{c|c|c|c}
\hline & \multicolumn{3}{|c}{ Hoop reinforcements $4 \phi$} \\
\cline { 2 - 4 } & A & B & $\begin{array}{c}\mathrm{c} \\
\text { (Spiral-hoop) }\end{array}$ \\
\hline Actual diameter $(\mathrm{mm})$ & 3.96 & 3.97 & 3.97 \\
\hline * Yield strength $\left(\mathrm{kg} / \mathrm{mm}^{2}\right)$ & 95.1 & 47.6 & 173.1 \\
\hline Tensile strength $\left(\mathrm{kg} / \mathrm{mm}^{2}\right)$ & 102.4 & 49.9 & 198.6 \\
\hline Young's modulus $\left(10^{4} \mathrm{~kg} / \mathrm{mm}^{2}\right)$ & 2.22 & 2.06 & 2.11 \\
\hline
\end{tabular}

Table 3 Mechanical properties of steel plates

\begin{tabular}{|c|c|c|c|}
\hline & & $\begin{array}{l}\text { Steel plate } \\
\mathbb{R}-5 \text { (Web) }\end{array}$ & $\begin{array}{l}\text { Steel plate } \\
\text { R-7 (flange) }\end{array}$ \\
\hline \multicolumn{2}{|c|}{ Standard classification } & SS400 & 55400 \\
\hline \multicolumn{2}{|c|}{ Actual thickness (mm) } & 4.58 & 6.42 \\
\hline \multirow{2}{*}{$\begin{array}{c}\text { Yield strength } \\
\left(\mathrm{kg} / \mathrm{mm}^{2}\right)\end{array}$} & upper & 37.0 & 32.3 \\
\hline & lower & 36.3 & 31.9 \\
\hline \multicolumn{2}{|c|}{ Tensile strength $\left(\mathrm{kg} / \mathrm{mm}^{2}\right)$} & 47.9 & 46.2 \\
\hline \multicolumn{2}{|c|}{ Elongation $(z)$} & 14.4 & 18.4 \\
\hline \multicolumn{2}{|c|}{$\begin{array}{c}\text { Young's modulus } \\
\left(10^{4} \mathrm{~kg} / \mathrm{mm}^{2}\right)\end{array}$} & 2.07 & 2.13 \\
\hline \multicolumn{2}{|c|}{ Poison's ratio } & 0.30 & 0.29 \\
\hline
\end{tabular}

Table 4 Mechanical properties of main reinforcement

\begin{tabular}{c|c}
\hline & $\begin{array}{c}\text { Main } \\
\text { Reinforcement } \\
\text { Deformed bar D1 3 }\end{array}$ \\
\hline Nominal diameter $(\mathrm{mm})$ & 12.7 \\
\hline Yield strength $\left(\mathrm{kg} / \mathrm{mm}^{2}\right)$ & 33.5 \\
\hline Ultimate strength $\left(\mathrm{kg} / \mathrm{mm}^{2}\right)$ & 51.2 \\
\hline Elongation $(8)$ & 28.7 \\
\hline Young's modulus $\left(10^{4} \mathrm{~kg} / \mathrm{mm}^{2}\right)$ & 2.01 \\
\hline
\end{tabular}




\section{3. 実験概要}

載荷システムおよび部材全体の変形を測定するシステ ムを Fig. 2 に示す。加力は，軸力を一定（50 ton）に保 ちながら, 試験体両端に逆対称変形を与えた。変形履歴 は, 部材変形角 $1 / 200$ (0.005 rad. ), 1/100 (0.01 rad.), 1/50 (0.02 rad. ), 1/25 (0.04 rad.) の正負で繰り返し, 最大 $1 / 12.5$ (0.08 rad. ) まで正方向に与えた。

試験体の材端モーメント $M$ と部材変形角 $R$ の関係を Fig. 3 に示す。図中,一点鎖線 ${ }_{c a l} M_{b}$ は後述する曲げ耐 力計算値を, 点線 $c a l M_{s}(\mathrm{a})$ はせん断耐力計算值 $(\mathrm{RC}$ 部 のせん断耐力は文献 3) のA 法による) を表している。 フープ筋間隔が小さい，すなわち，フープ筋比が大きい ほど最大耐力は大きい。同じフープ筋間隔のものを比べ ると, フープ筋間隔が大きい $(10 \mathrm{~cm})$ 場合は, フープ 筋強度の高いほう（SRC-100-A-R） が最大耐力は大き い。フープ筋間隔が $5 \mathrm{~cm}, 2 \mathrm{~cm}$ の場合は, フープ筋強 度の影響は最大耐力にはほとんど現れず，最大耐力後の 耐力低下に影響が現れている。すなわち，せん断補強量 (フープ筋比 $P_{w}$ とフープ筋の降伏点強度 $\sigma_{w y}$ の積, $P_{w} \cdot \sigma_{w y}$ と考える）が大きいほ亡゙, 耐力低下が少なく, 復元力特性が安定している。
すべての試験体で，対角線方向に斜めひびわれが生じ た。斜めひびわれの本数，幅が大きくなり，最大耐力に 達した後, 対角線方向のひびわれに沿ってコンクリート が圧壊するという破壊形態を示した。いずれの試験体に おいてもフープ筋は破断するには至らなかった。せん断 補強量が最も小さい SRC-100-B-R は，実験の最終サ イクルの大変形時において軸力を保持できなくなった。 各試験体の実験終了後の状況を Photo. 1(a)～(g) に示 す。

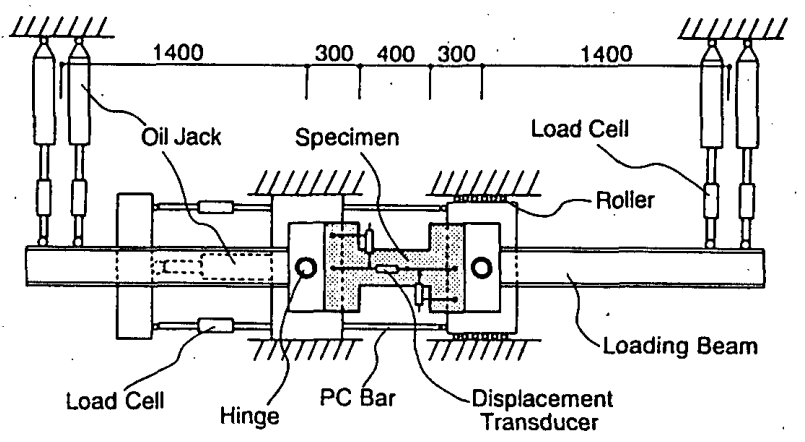

Fig. 2 Loading setup

Table 5 Mix proportion of concrete

\begin{tabular}{|c|c|c|c|c|c|c|c|}
\hline \multirow{2}{*}{$\begin{array}{l}\text { W/C } \\
(\%)\end{array}$} & \multicolumn{2}{|r|}{$\operatorname{Mix}$} & proportion & of concrete & $\left(\mathrm{kg} / \mathrm{m}^{\mathrm{m}}\right)$ & \multirow{2}{*}{$\begin{array}{l}\text { Maximum } \\
\text { aggregate size } \\
(\mathrm{mm})\end{array}$} & \multirow{2}{*}{$\begin{array}{l}\text { Admixture } \\
(\mathrm{C} \times \%)\end{array}$} \\
\hline & Water & Cement & Coarse & aggregate & Fine aggregate & & \\
\hline 40 & 185 & 463 & & 980 & 680 & 10 & $0.5 \sim 1.0$ \\
\hline
\end{tabular}

Table 6 Mechanical properties of concrete

\begin{tabular}{|c|c|c|c|c|c|c|c|}
\hline Specimen & $\begin{array}{c}\text { Age } \\
\text { (days) }\end{array}$ & $\begin{array}{c}\text { Compressive } \\
\text { strength } \\
\left(\mathrm{kg} / \mathrm{cm}^{2}\right)\end{array}$ & $\begin{array}{c}\text { Strain at the } \\
\text { maximum stress } \\
(\%)\end{array}$ & $\begin{array}{c}1 / 3 \sigma B \\
\text { Secant Modulus } \\
\left(10^{5} \mathrm{~kg} / \mathrm{cm}^{2}\right)\end{array}$ & $\begin{array}{l}\text { Splitting } \\
\text { tensile } \\
\text { strength } \\
\left(\mathrm{kg} / \mathrm{cm}^{2}\right)\end{array}$ & $\begin{array}{l}\text { Compressive } \\
\text { strength } \\
\left(\mathrm{kg} / \mathrm{cm}^{2}\right)\end{array}$ & $\begin{array}{c}\text { splitting } \\
\text { tensile } \\
\text { strength } \\
\left(\mathrm{kg} / \mathrm{cm}^{2}\right)\end{array}$ \\
\hline$S R C-20-A-R$ & 47 & .605 & 0.28 & 3.19 & 41.9 & 555 & 40.6 \\
\hline SRC-20-B-R & 50 & 578 & 0.31 & 3.12 & 34.4 & 555 & $\therefore 40.6$ \\
\hline$S R C-20-C-R$ & 54 & 657 & 0.30 & 3.54 & 43.1 & 642 & 44.2 \\
\hline$S R C-50-A-R$ & 35 & 612 & 0.27 & 3.17 & 47.1 & 533 & 48.0 \\
\hline$S R C-50-B-R$ & 39 & 659 & 0.32 & 3.16 & 35.6 & 533 & 48.0 \\
\hline$S R C-100-A-R$ & 46 & 640 & 0.29 & 3.25 & 41.5 & 583 & 45.1 \\
\hline SRC-100-B-R & 40 & 635 & 0.33 & 3.00 & 40.2 & 583 & 45.1 \\
\hline \multirow{2}{*}{\multicolumn{2}{|c|}{$\begin{array}{l}\text { Diameter and heigl } \\
10 \mathrm{~cm} \phi \times 20 \mathrm{~cm} \\
10 \mathrm{~cm} \phi \times 10 \mathrm{~cm} \\
\text { Curing procedures }\end{array}$}} & $\begin{array}{l}\text { ht of cylinde } \\
\text { h /for compr } \\
\text { h } \text { (for split }\end{array}$ & $\begin{array}{l}\text { ers: } \\
\text { ressive strengt } \\
\text { tting tensile s }\end{array}$ & $\begin{array}{l}\text { =h tegt) } \\
\text { strength test) }\end{array}$ & & \multirow[t]{4}{*}{$\begin{array}{l}\text { 1day Moist } \\
\text { 27days Water }\end{array}$} & \multirow[t]{4}{*}{$\begin{array}{l}\text { Curing, } \\
\text { Curing }\end{array}$} \\
\hline & & of concrete & cylinders and & specimens & & & \\
\hline \multirow{2}{*}{\begin{tabular}{|c|}
\multicolumn{2}{c|}{ Placed } \\
in forms
\end{tabular}} & Moist & curing & Removal & $\begin{array}{l}\text { ed in the air } \\
\text { the laboratory }\end{array}$ & \multirow{2}{*}{ Test } & & \\
\hline & $7 d$ & & f forms & $8 \sim 47$ days & & & \\
\hline
\end{tabular}



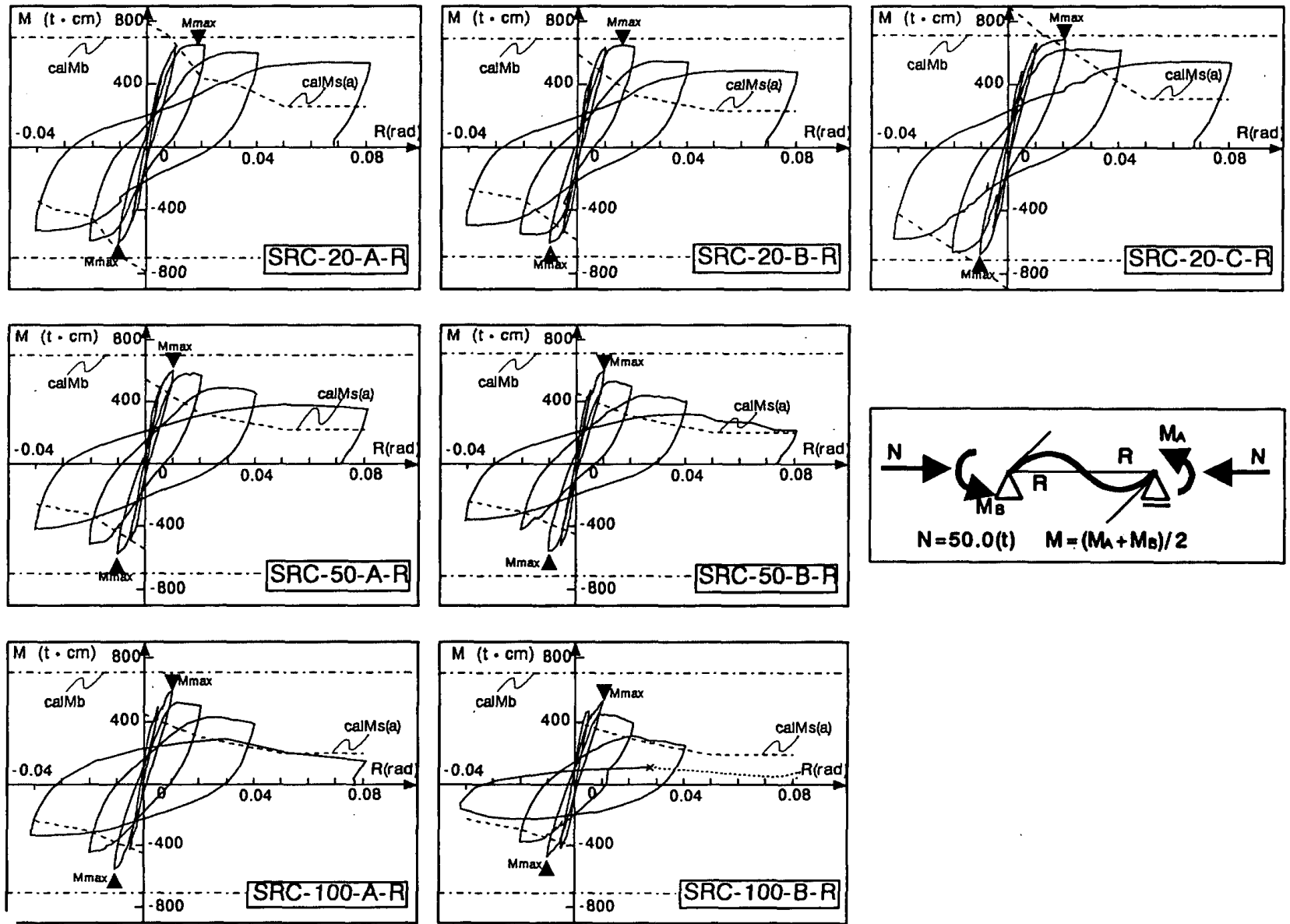

Fig. 3 Load-deflection curves

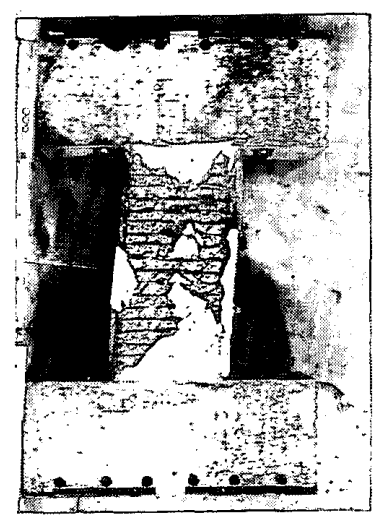

(a) SRC-20-A-R

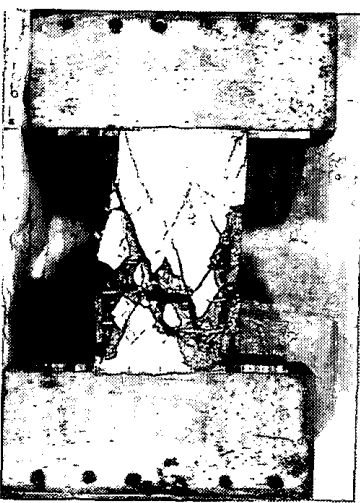

(e) SRC-50-B-R

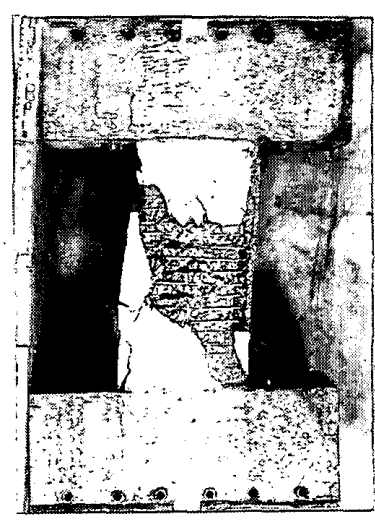

(b) SRC-20-B-R

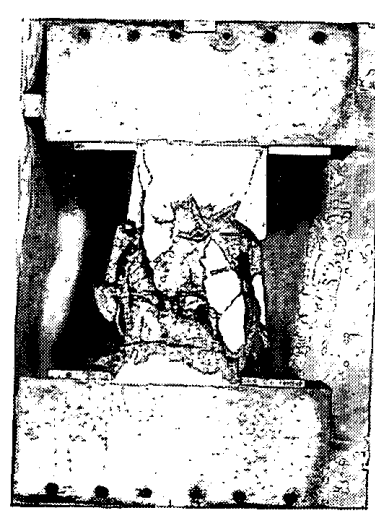

(f) SRC-100-A-R

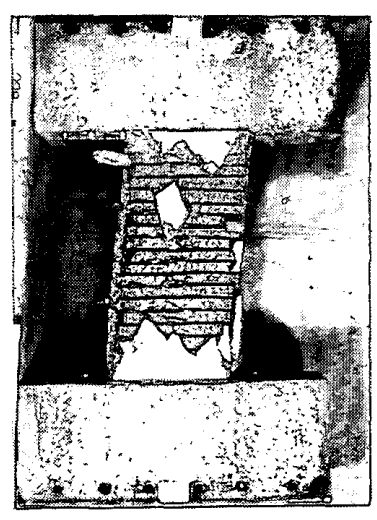

(c) SRC-20-C-R

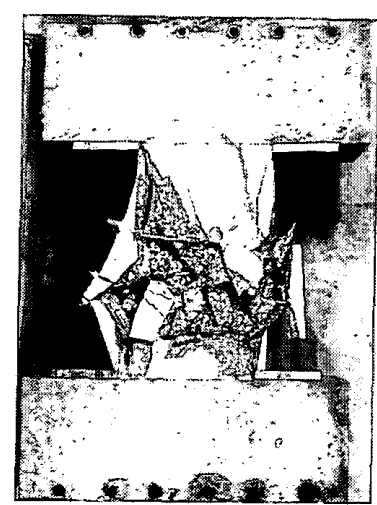

(g) SRC-100-B-R

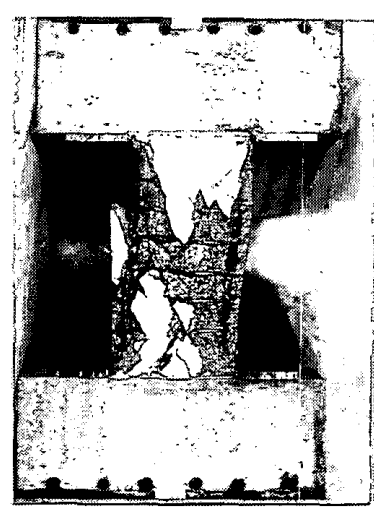

(d) SRC-50-A-R

Photo 1 Specimens after test 


\section{4. 結果の検討}

Fig. 4 は，フープ筋間隔が $2 \mathrm{~cm}$ の試験体（SRC-20$\mathrm{A}-\mathrm{R}, \mathrm{B}-\mathrm{R}, \mathrm{C}-\mathrm{R})$ およびフープ筋間隔が $5 \mathrm{~cm}$ で高強 度のフープA を用いた試験体 (SRC-50-A-R)について, 最大耐力時の主筋のひずみを示している。図中の丸印は 最大耐力時のひずみを，実線はそれまでに経験したひず み履歴の範囲を示す。フープ筋間隔が $2 \mathrm{~cm}$ で高強度の フープ A および C を用いた試験体（SRC-20-A-R， C-R) の主筋は降伏し，フープ B を用いた試験体 (SRC20-B-R）の主筋は降伏あるいは降伏直前，フープ筋間 隔が $5 \mathrm{~cm}$ の試験体（SRC-50-A-R）の主筋は降伏して いない。フープ筋間隔が $2 \mathrm{~cm}$ で高強度のフープ A およ びCを用いた試験体（SRC-20-A-R，C-R）は，曲げ 降伏し，曲げにより最大耐力が定まり，その後，せん断

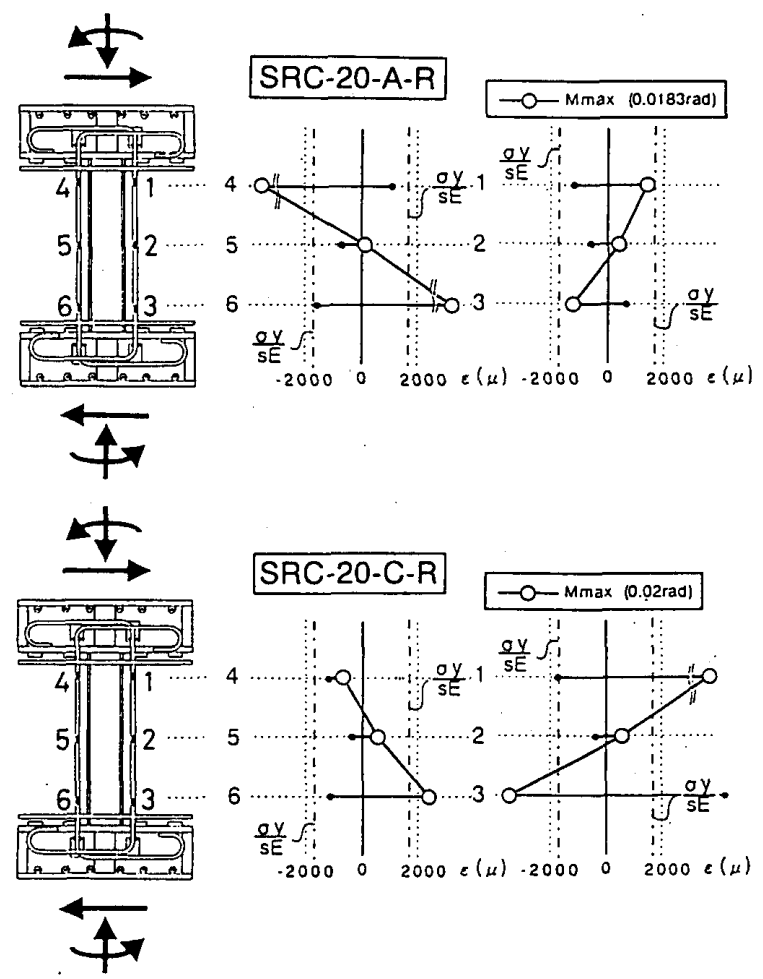

破壊する曲げせん断破壊，フープ筋間隔が $5 \mathrm{~cm}$ および $10 \mathrm{~cm}$ の試験体は，曲げ降伏せず，せん断により最大耐 力が定まる曲げ降伏前のせん断破壊であったと言える。

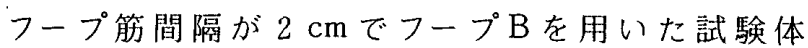
(SRC-20-B-R) は，曲げ降伏直前あるいは降伏と同 時にせん断破壊し，最大耐力はせん断によって決まった と考えられる。

高強度フープ筋 $\mathrm{A}$ を用いた試験体のうち SRC50-A-R および SRC-100-A-R のフープ筋のひずみを Fig. 5 に示す。最大耐力時 (黒丸印) に, 降伏点強度を 縦弾性係数で除した值（約 $4000 \mu)$ ，あるいは，その $3 / 4$ 程度の值（約 $3000 \mu$ ) となっている。前報)での偏 心圧縮単調載荷奏験における同様な試験体では，少なく とも 1 本のフープ筋は最大耐力時に降伏していたが，本

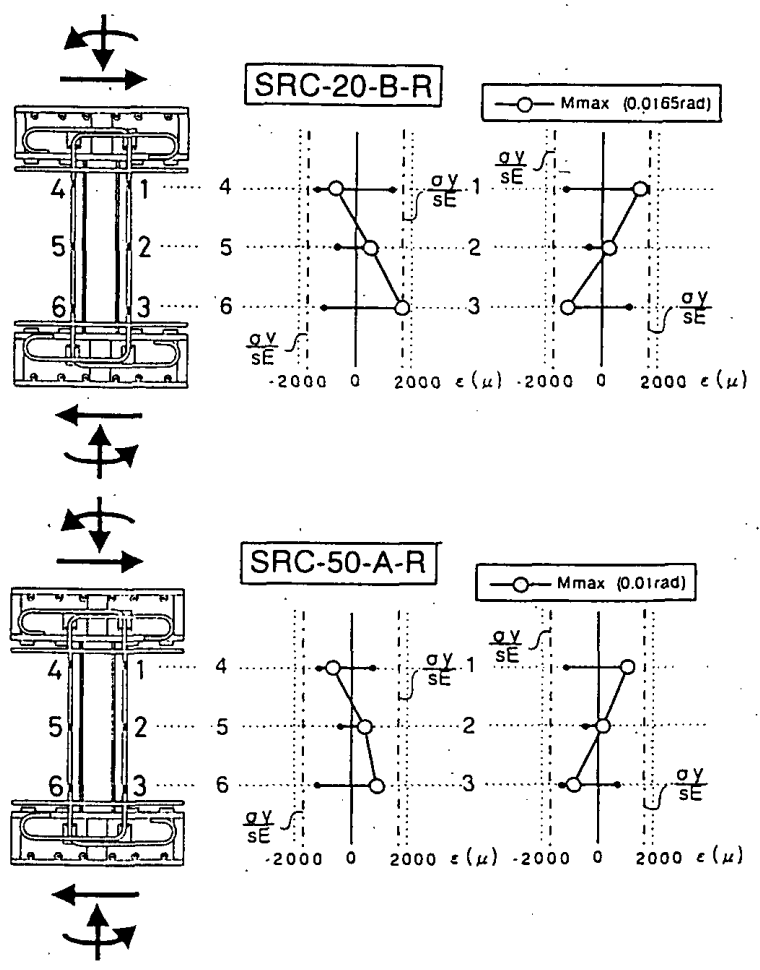

Fig. 4 Strain of main reinforcement
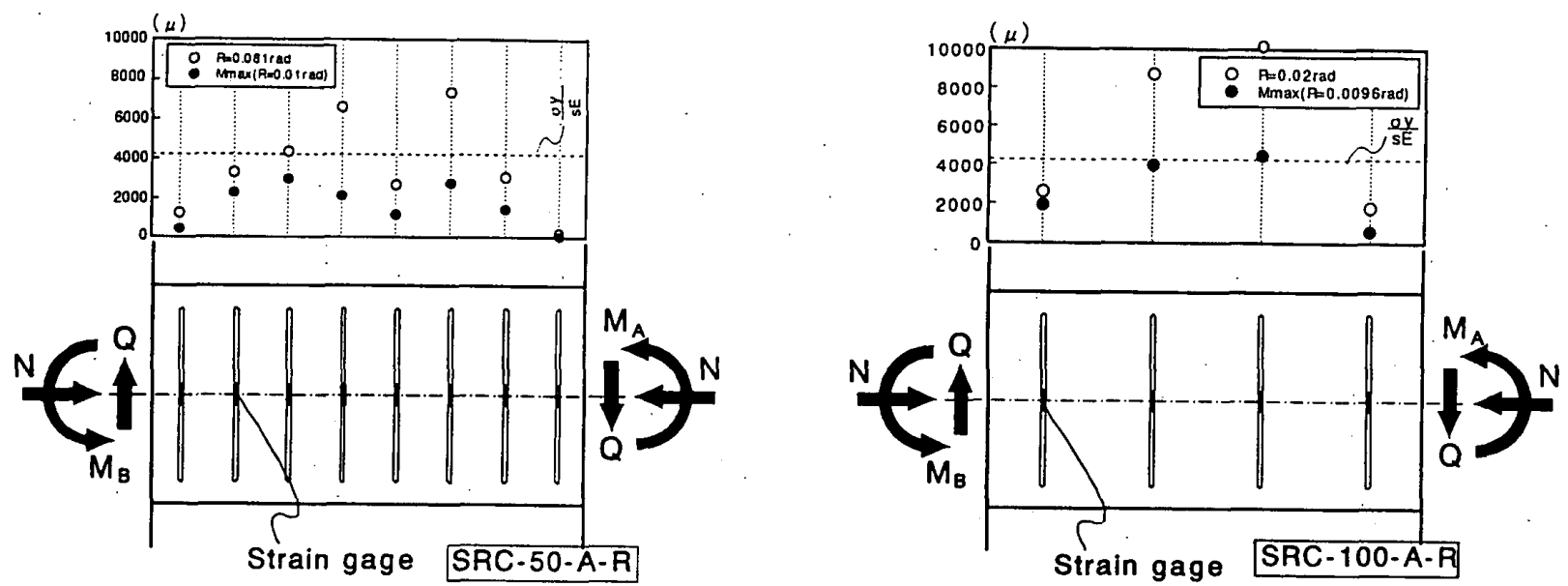

Fig. 5 Strain of hoop reinforcement 

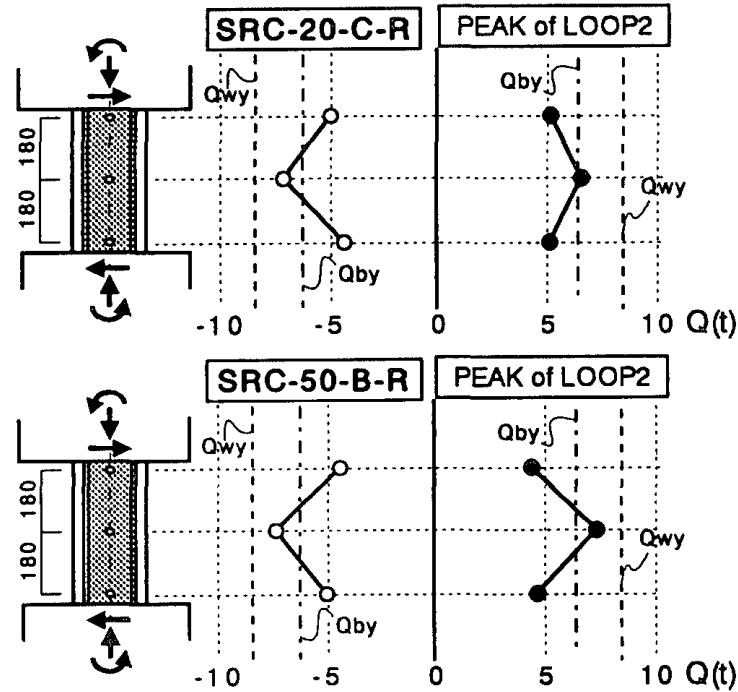
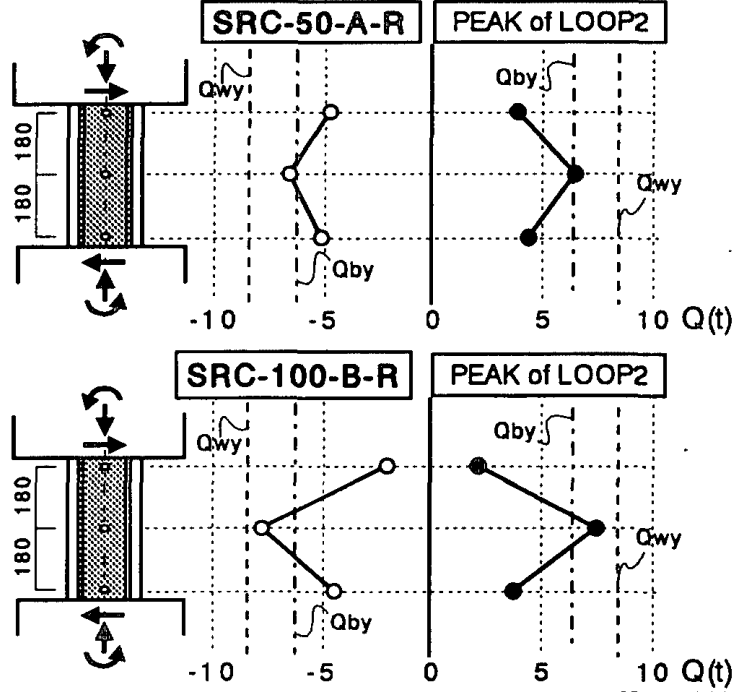

Fig. 6 Shear force developed in steel

繰り返し載荷実験では,フープ筋は最大耐力時には降伏 に至らず，降伏に達するのは大変形時においてである。 降伏点強度が $9000 \mathrm{~kg} / \mathrm{cm}^{2}$ 級のフープ筋の高強度特性 は，最大耐力時に最大限有効には働かず，その有効性は 変形量に依存していると考えられる。

Fig.6は，試験体 SRC-20-C-R，SRC-50-A-R, B-R および SRC-100-B-R について，部材角 $1 / 100$ $\mathrm{rad}$.の繰り返しループの正負ピーク時（試験体 SRC20-C-Rを除き最大耐力時に対忘する。試験体 SRC20-C-Rにおいても，その耐力はほぼ最大耐力に等しい。 Fig. 3 参照) における試験体柱の中央部（反曲点）と柱 頭・柱脚部位置での小鉄骨の負担せん断力を表してい る。小鉄骨の負担せん断力は，鉄骨ウエブ中央に貼付し た 3 方向ひずみゲージより求めたせん断応力度に鉄骨ウ エブ断面積（フランジ重心間距離 ${ }_{s} d \times$ エブ厚 $t_{w}$ ）を 乗じた值である。鉄骨ウエブ中央位置でのせん断応力度 はいずれの場合も，von Misesの降伏条件によれば弾性 限内である。図中,一点鎖線 $Q_{b y}$ は，部材端の鉄骨の 全塑性モーメントから定まる降伏耐力（鉄骨の全塑性 モーメントを材長の $1 / 2$ の長さで除したせん断力）を， 破線 $Q_{w y}$ は，鉄骨ウエブのせん断降伏耐力である。い ずれの試験体においても，鉄骨の負担せん断力は材軸に 沿って一様ではなく，材端部に比へ，材中央部で大きく なっている。このことは, せん断力がコンクリートから 鉄骨へ，また，鉄骨からコンクリートへと伝達されてい ることを示唆している。材中央部での鉄骨の負担せん断 力は, いずれの試験体においても，鉄骨の曲げによるせ ん断耐力 $Q_{b y}$ 以上である。すなわち, 試験体の破壊モ一 ドにかかわらず，小鉄骨は，少なくともQ $Q_{b y}$ のせん断 力を負担している。この実験結果は, 文献 2) の本会規 準の鉄骨が負担できるせん断力の規定を肯定するもので ある。
曲げ耐力について，計算値と実験値の比較を行う。試 験体断面の曲げ耐力の計算值を求めるにあたり, 次のよ うな仮定を設定した。断面の曲げ耐力は累加則注)が適用 しうること，すなわち，コンクリート，鉄骨，鉄筋ともに 㴊塑性とする。その応力は, コンクリートの引張り側は 零，圧縮はシリンダー王縮強度 $\left(\sigma_{B}\right)$, 鉄骨および鉄筋 は引張り圧縮共降伏点強度 $\left(\sigma_{y}\right)$ とする。このようにし て求めた軸力 $(N)$-曲げモーメント $(M)$ 関係を, 曲げ で耐力が定まった試験体 SRC-20-A-R および 20-C-R について, Fig.7 に示す。白丸印が計算值 ${ }_{c a l} M_{b}$ を, 黒 丸印が実験值 ${ }_{e x} M$ (小さい黒丸印で示す耐端 ${ }_{e x} M_{A}$, ${ }_{e x} M_{B}$ の平均值）を表す。図中の一点鎖線 ${ }_{c a l} M_{s}(\mathrm{a}),(\mathrm{b})$ は, 後に述べるせん断耐力計算値 $c a l Q_{s}$ を曲げモーメン 卜 $\left({ }_{c a l} M_{s}={ }_{c a l} Q_{s} \cdot 20 \mathrm{~cm}\right)$ に置換したものである。両試 験体の実験值は曲げ耐力計算値を下回った。この計算値 は, 前述のごとくコンクリートを剖塑性とし, その王縮 応力をシリンダ一強度としたものである。ここで, コン クリート部の耐力を再評価する。すなわち，奏験值に合 うように，コンクリートの有効圧縮応力を逆算する。こ のようにして求めた有効圧縮応力の大きさは, シリン ダ一圧縮強度に対して試験体 SRC-20-A で 0.77, 試験 体 SRC-20-C で 0.86 となる。コンクリートの有効圧縮 応力をシリンダー強度の約 0.8 程度に低減し, 前述の仮 定，すなわち，累加則を適用することで繰り返し荷重下 における曲げ耐力を評価できると言える。

この低娍係数 0.8 は, 本会規準 ${ }^{21}$ で規定されている值 $\left(0.85-2.5{ }_{s} p_{c}=0.83\right)$ より若干小さい。この理由と しては, 鉄骨断面が比較的小さいこと, コンクリート強 度が $600 \mathrm{~kg} / \mathrm{cm}^{2}$ 級の高強度であること, 繰り返し載荷 の影響を受けていること，等が考えられるが，その理由 を特定することはできない。しかし，本夷験の結果は， 累加則の考え方に従う限り, 鉄骨断面が小さいことを理 
由にしては説明し難い。すなわち，鉄骨断面が柱断面の 中心に集中していると考えると, 鉄骨は軸力のみを負担 し, 曲げモーメントは負担しなくなるが, その場合でも， 本実験の軸力レベルでは，SRC断面の累加強度は Fig. 7 の計算值とほとんど同じになるからである。また， 試験体 SRC-20-A-R，20-C-R について，鉄骨部のせん 断力分布を測定点間で線形補間したものと考え（Fig.6 参照), 材中央の曲げモーメントを零として， せん断力 分布から鉄骨が負担している材端曲げモーメントを計算 すると，全塑性モーメントの約 $90 \%$ 程度になる。鉄筋 のひずみ測定結果 (Fig. 4 参照) から, 鉄筋も相当大き な曲げモーメントを負担していると言える。これらのこ とからも，累加則の考え方を使う限り，コンクリートの 有効圧縮応力をシリンダー強度の 0.8 程度と考えるのが 最も適切であると言える。

せん断耐力について，実験値と計算値を比較する。せ ん断耐力の計算のための仮定は以下のとおりである。 $\mathrm{SRC}$ の耐力は鉄骨部と RC 部の耐力の和とする。 $\mathrm{RC}$ 部は全断面が有効であると考える。 $\mathrm{RC}$ 部のせん断耐力 は, 文献 3）の本会指針・同解説の第 6 章・第 3 節に述 ベられているA 法および B 法による。ただし, 文献 3)

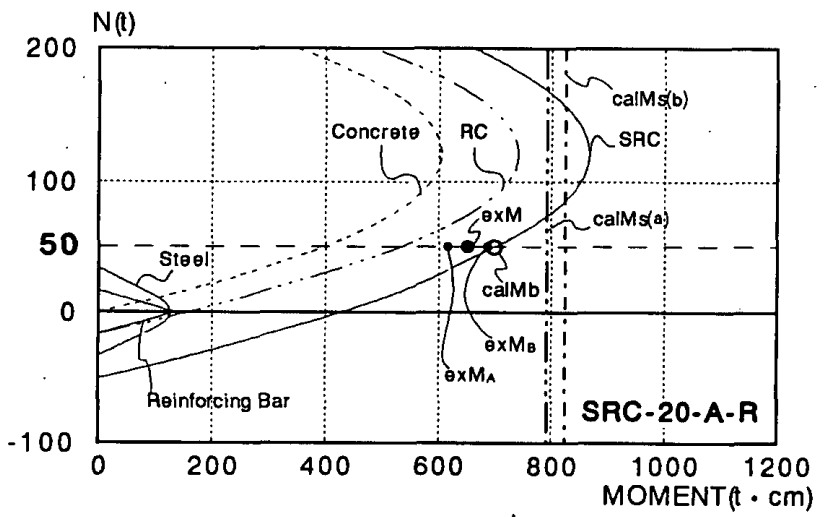

の制限 $\sigma_{w y} \leqq 25 \sigma_{B}$ は無視し， $\sigma_{w y}$ はコンクリート強度と は無関係に, 使用したフープ筋の降伏点強度とした。高 強度補強筋のせん断補強効果を調べることが奏験の目的 の一つであること，および文献 4) でも指摘しているよ うに， $\sigma_{w y} \leqq 25 \sigma_{B}$ の制限に理論的根拠が無いことが理由 である。

Fig. 8 は計算值と実験值を材端モーメントで表したも のである。棒グラフはせん断耐力計算值（試験体名の後 ろの記号（a）はA 法を，(b)はB 法を表す）を,一 点鎖線は曲げ耐力計算值 ${ }^{2} a l M_{b}$ を, 黒丸印は実験值 ${ }_{e x} M$ を表している。鉄骨のせん断耐力計算值 $s M$ は, 部材端 の全塑性モーメントから定まる值である。

せん断耐力計算値が曲げ耐力計算值より明らかに小さ く, かつ, 実験でもせん断で耐力が定まった試験体 (SRC-50-A-R, B-R および SRC-100-A-R, B-R) お よび, せん断耐力計算値と曲げ耐力計算值がほぼ等しく, 奏験でも曲げ降伏と同時にせん断破壊している試験体

(SRC-20-B-R) の実験值はA 法によるせん断耐力計 算値を上回り，B 法による計算値を若干下回っている。

曲げで耐力が定まる場合の, 曲げ降伏後の曲げせん断 耐力について検討する。 RC 部の曲げ降伏後のせん断耐

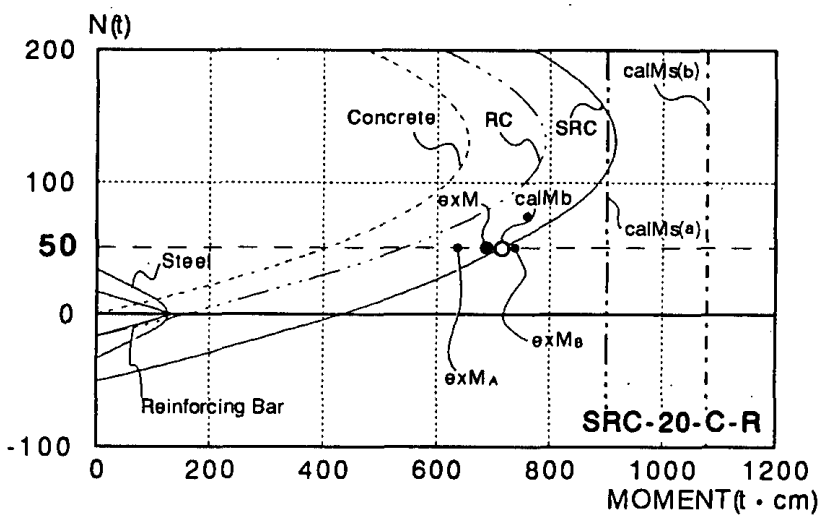

Fig. 7 M-N interaction and test results

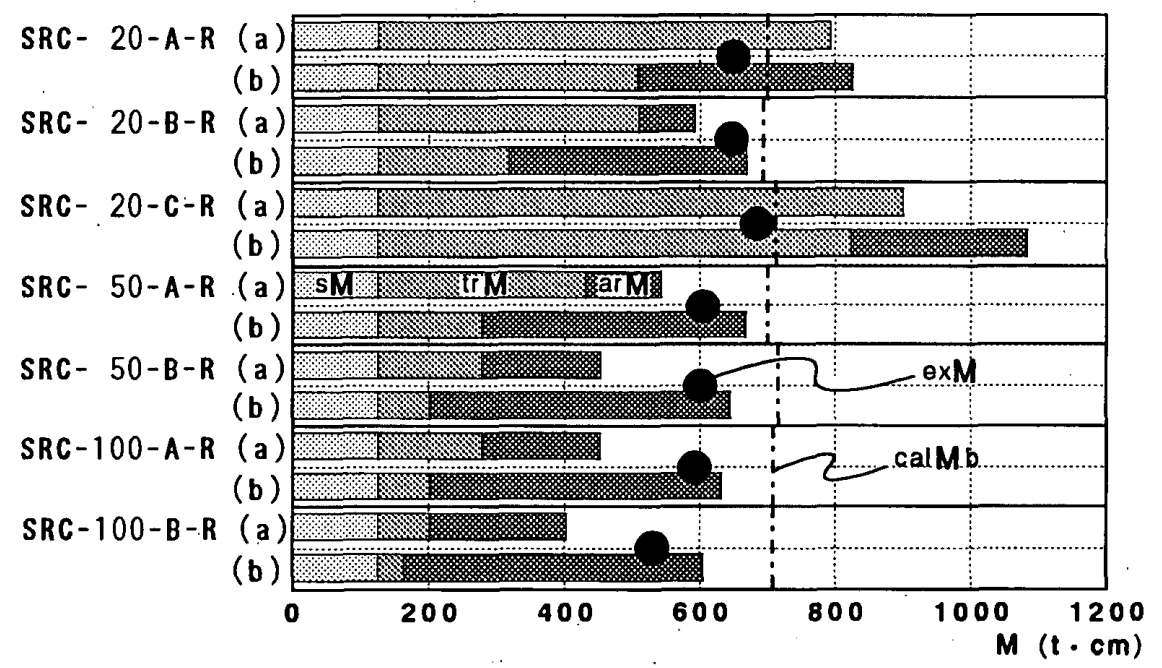

Fig. 8 Analytical and experimental strength 


\section{$R(\mathrm{rad})$}

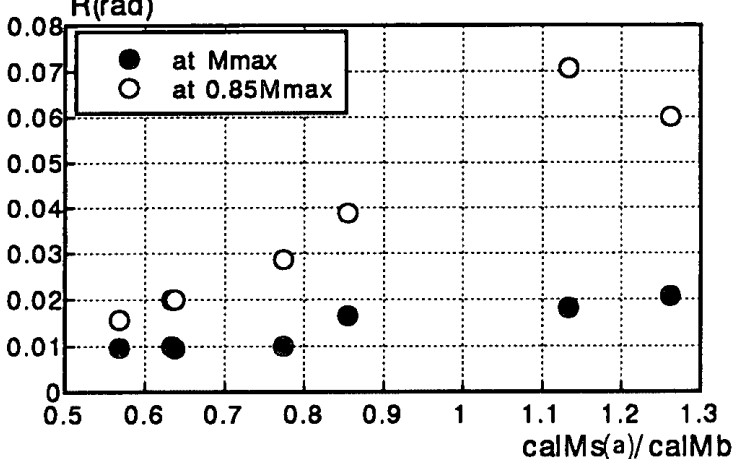

Fig. 9 Relationship between $\mathrm{R}$ (at $\left.M_{\max } \& 0.85 \cdot M_{\max }\right)$ and ( ${ }_{\text {cal }} M_{s} /{ }_{\mathrm{cal}} M_{b}$ ) value

力は $\mathrm{A}$ 法により，その算定にあたっては，塑性ヒンジ 回転角 $R_{p}=$ 部材変形角 $R$ とした。Fig. 3 に示すように, 曲げで耐力が定まった試験体（SRC-20-A-R, C-R）の 曲げ降伏後の曲げせん断耐力の実験値は，A 法による せん断耐力計算值を上回っている。 RC 部のせん断耐力 を A 法で算定し，鉄骨部のせん断耐力と累加すること で, 本研究で対象としている SRC 柱のせん断耐力を, 曲げ降伏後のせん断耐力も含めて安全側に評価できるこ とを示している。A 法は実験結果を適切に評価してい るわけではないが，せん断耐力の評価にあたっては，安 全側に評価することを最優先させることとした。

せん断補強量 $P_{w} \cdot \sigma_{w y}$ が大きいほよ゙, 大変形時まで複 元力特性が安定していることが, Fig. 3 からもわかる。 ここでは，せん断耐力計算值（A 法による）と曲げ耐 力計算値との比 $\left({ }_{c a l} M_{s}(a) /{ }_{c a l} M_{b}\right)$ 之最大荷重時の変形 および荷重が最大の 0.85 倍になった時の変形の関係を 検討する。Fig. 9 に示すように, $\left({ }_{c a l} M_{s} /{ }_{\mathrm{cal}} M_{b}\right)$ の值が 大きいほど，大変形時まで復元力特性を安定させる，す なわち，変形能力を高める効果があるといえる。

\section{5. 結}

比較的断面の小さい鉄骨, 高強度のコンクリートおよ びフープ筋を用いた SRC 柱について一定軸力下での繰 り返し曲げせん断実験を行い，以下の結論を得た。

1）フープ筋の働きは，フープ筋の量と柱の変形量によ る。したがって, 高強度フープ筋が必ずしも最大耐力時 に最大限有効に働くとは限らない。

2）しかしながら, 降伏点強度 $9000 \mathrm{~kg} / \mathrm{cm}^{2}$ 級の高強 度フープ筋および生縮強度 $600 \mathrm{~kg} / \mathrm{cm}^{2}$ 級の高強度コン クリートを用いた場合，コンクリートの全断面が有効に 働くと考え，かつ，フープ筋強度を低減することなく文 献 3）の $\mathrm{A}$ 法に基づき算定した $\mathrm{RC}$ 部のせん断耐力と 鉄骨部のせん断耐力を累加することにより，SRC 柱と してのせん断耐力を安全側に評価できる。

3）圧縮強度 $600 \mathrm{~kg} / \mathrm{cm}^{2}$ 級の高強度コンクリートを用 いた場合，累加則を適用して曲げ耐力を算定するにあ
たっては，コンクリートのストレスブロックの有効圧縮 応力をシリンダー圧縮強度の 0.8 倍程度とするとよい。

4) 単調載荷の柱と同様に, せん断耐力計算值/曲げ耐 力計算值が大きければ，大変形時でも耐力低下の少ない 安定した復元力特性, すなわち, 大きい変形能力が得ら れる。

5）小鉄骨は，せん断力を材軸に沿ってコンクリートか ら鉄骨へ，また，鉄骨からコンクリートへと伝達するの に有効に働いている。本実験では，すべての試験体で， 鉄骨は材中央で，鉄骨断面の全塑性モーメントを材長の $1 / 2$ の長さで徐したせん断力 $Q_{b y}$ 以上のせん断力を伝達 している。

\section{参考文献}

1）瀧口克己，長鴄俊雄，梅林一貫：高強度材料を用いた小 鉄骨 SRC 柱の耐力, 日本建築学会構造系論文集, No. 458, pp. 145 152, Apr., 1994

2）「鉄骨鉄筋コンクリート構造計算規準・同解説」，日本建 築学会, 1987 制定

3）「鉄筋コンクリート構造物の終局強度型耐震設計指針・同 解説」, 日本建築学会, 1990 制定

4）市之瀬敏勝，横尾慎一：せん断補强間隔が RC 梁のせん 断強度に及ぼす影響, 日本建築学会構造系論文報告集, No. 437, pp. 97 103, July, 1992

注)

累加則を一般的に表現すれば，次のようになる。 全体系 $S_{r}$ が， $S_{1} ， S_{2}, \cdots S_{i}, \cdots S_{n}$ の $n$ 個の系によって構成さ れているものとする。各系 $S_{i}$ は, 各系の境界条件の制約の下, $f_{i}\left(X_{1 i}, X_{2 i}, \cdots X_{j i}, \cdots X_{m i}\right) \leqq 0$ なる条件で, その成分が $X_{1 i}, X_{2 i}$, $\cdots X_{j i}, \cdots X_{m i}$ なる力を伝達できるとする。この場合, 全体系 $S_{T}$ は, 力の各成分 $X_{j \tau}$ が $f_{i}\left(X_{i i}, X_{2 i} \cdots X_{j i}, \cdots X_{m i}\right) \leqq 0$ の条件を満 足する各系の力の成分 $X_{j i}$ に分解可能であれば，すなわち， $X_{j T}$ $=\sum_{i=1}^{n} X_{j i}$ で表せれば, $X_{1 T}, X_{2 T}, \cdots X_{J T}, \cdots X_{m T}$ を成分とする力を 伝達できる。

言葉をかえて, $f_{i}\left(X_{1 i}, X_{2 i}, \cdots X_{\lrcorner l}, \cdots X_{m i}\right) \leqq 0$ の条件を満足さ せる $S_{1}, S_{2}, \cdots S_{l}, \cdots S_{n}$ 各系の力の成分の和を包絡する条件を， $f_{T}\left(X_{1 T}, X_{2 r}, \cdots X_{j T}, \cdots X_{m T}\right)=0$ とすれば，全体系 $S_{T}$ は， $f_{T}$ $\left(X_{1 T}, X_{2 T}, \cdots X_{j T}, \cdots X_{m T}\right) \leqq 0$ を満足する $X_{1 T}, X_{2 T}, \cdots X_{j T}, \cdots X_{m r}$ を成分とする力を伝達できるということもできる。

各系の力の成分 $X_{1 i}, X_{2 i}, \cdots X_{j i}, \cdots X_{m i}$ を一般化応力と考元, $f_{i}\left(X_{1 i}, X_{2 i}, \cdots X_{j i}, \cdots X_{m i}\right)=0$ を降伏面として, 塑性論に従えば, $f_{i}\left(X_{1 i}, X_{2 i}, \cdots X_{j i}, \cdots X_{m l}\right)=0$ の面は, $X_{1 i}, X_{2 i}, \cdots X_{j l}, \cdots X_{m i}$ 座 標で，原点に関して外側に凸になる。 $f_{T}=0$ も同様に外側に凸 な面になる。特別な条件下ではあるが，二軸の曲げモーメント $M_{1}, M_{2}$ と二軸の曲げ変形 $\phi_{1}, \phi_{2}$ との関係は, $M_{1}, M_{2}$ を一般化 応力， $\phi_{1} ， \phi_{2}$ を一般化ひずみとして，塑性論と完全に一致する ことが示されている ${ }^{\mathrm{A}-11}$ 。

曲げ材断面の曲げモーメント $M$ と軸力 $N$ のように，力の成 分が二次元で表せる場合, $f_{i}\left(X_{1 i}, X_{2 i}\right)=f_{i}\left(M_{i}, N_{i}\right)=0$ の面に, 原点に関して外側に凸になる条件があれば, $f_{T}\left(X_{1 T}, X_{2 T}\right)=f_{T}$ $\left(M_{T}, N_{T}\right)=0$ の近似解は, 図を用いて比較的簡便に求めること ができる。

曲げ材の断面が 2 種類の材料で構成され，各材料の応力とひ 
ずみの関係が㴊塑性であり，対称曲げが仮定できる場合，断面 の平面保持を仮定して求めた曲げモーメントー軸力の耐力曲線と 累加則で求めた耐力曲線は完全に一致することが証明されてい $ろ^{\mathrm{A}-2)}$ 。構成材料を $n$ 種に拡張することはきわめて簡単である。 本論では，断面の曲げモーメント $M$-軸力 $N$ 相関曲線を取り 扱っており，断面の平面保持と材料の㴊塑性を仮定したことと 同一の意味になる糸加則を用いている。本会の SRC 規準では， 一般化累加と呼んでいる方法である。
A-1）鈴木, 滝口, 岡本, 加藤： SRC 部材の復元力特性に対 するフープ筋の効果に関する奏験, 日本建築学会構造系 論文報告集, No. 348, pp. 61 74, Feb., 1985

A-2）滝口，木村，黒正，小林：水平 2 方向変位に対する $\mathrm{RC}$ 柱の復元力に関する研究，日本建築学会論文報告集, No. 296, pp. $77 \sim 87$, Nov. , 1970

(1994 年 5 月 10 日原稿受理, 1994 年 10 月 14 日採用决定) 